\title{
Distribution and abundance of benthic and demersal macrofauna within a natural hydrocarbon seep
}

\author{
David J. Steichen, $\mathrm{Jr}^{1}$, Sally J. Holbrook ${ }^{1, *}$, Craig W. Osenberg ${ }^{2}$ \\ ${ }^{1}$ Dept of Ecology, Evolution and Marine Biology, University of California at Santa Barbara, Santa Barbara, \\ California 93106, USA \\ ${ }^{2}$ Dept of Zoology, University of Florida, Gainesville, Florida 32611-8525, USA
}

\begin{abstract}
Natural oil seeps provide a heightened supply of organic carbon that can potentially result in higher numbers of infaunal organisms, yet toxic effects of oil or its by-products could have negative impacts. These contrasting influences make oil seeps an ideal setting to investigate the effects of a tradeoff between enrichment and toxicity. We explored small-scale (1 to $10 \mathrm{~m}$ ) spatial patterns of distribution of infauna and physical and chemical characteristics of sediments within an oil seep area located near Santa Barbara, California, USA. Correlation and principal components analyses revealed that physicochemical parameters of the sediments (dissolved sulfide, volatile solids, organic carbon and nitrogen, sediment grain size) generally covaried with one another; oil-rich samples had large grain size and high concentrations of organic material. Densities of nematodes were positively correlated with amount of oil present, whereas all other major taxa (polychaetes, gammarids, oligochaetes, bivalves, copepods, ostracods, cumaceans) were negatively correlated. These results contrasted with patterns that we observed at a much larger spatial scale (up to $1 \mathrm{~km}$ ) where the number of organisms colonizing trays of clean sediments was greater at 2 seepage sites compared to 2 sites that lacked seeps. A field experiment tested the effects of hydrocarbon seepage on the distribution and abundance of macrofauna. Colonization by infauna was assessed in trays of sediments that varied in organic enrichment (clean sediment, sediment with fresh oil, weathered oil, or sulfide). The results were consistent with small-scale (within-seep) patterns observed in the field survey; after $24 \mathrm{~h}$, nematode densities were 3 times higher in the enriched trays, whereas all other taxa were most abundant in the clean trays. The results suggest that the biological effects of oil seepage are scale-dependent and that behavioral mechanisms involving microhabitat selection may contribute to the observed spatial patterns of distribution.
\end{abstract}

KEY WORDS: Macrobenthos · Hydrocarbon seeps · Organic enrichment

\section{INTRODUCTION}

The discharge of organic material is a common source of anthropogenic impacts in marine environments. Such releases can arise from a variety of activities, including discharge of treated sewage or by-products of oil processing, as well as accidental spills of petroleum products. Predicting the response of organisms to organic enrichment is difficult due to the diversity of direct and indirect effects that are possible (Pearson \& Rosenberg 1978, Gray 1981). Positive

\footnotetext{
- Addressee for correspondence.

E-mail: holbrook@lifesci.ucsb.edu

effects can arise from an enriched food supply that results from increased organic matter and microbial activity (Spies et al. 1980, Gray 1981, Spies \& DesMarais 1983, Levin 1986, Bartha \& Atlas 1987, Montagna et al. 1989, Weston 1990). Adverse effects on organisms can result from toxicity of particular organic compounds or chemical by-products of their metabolism or degradation, such as sulfide and ammonia (Pearson \& Rosenberg 1978, Bartha \& Atlas 1987, Thompson et al. 1989, Sandulli \& De Nicola 1991). Some organisms might also be affected by secondary physical and chemical changes in the sediment resulting from the aggregation of particles or changes in bioturbation of the sediments by the resident organisms (Aller 1983, Rhoads \& Boyer 1983). 
The overall abundance of organisms in areas of organic enrichment can be influenced by several conflicting factors (Pearson \& Rosenberg 1978, Gray 1981), giving rise to a spatial pattern of low densities near the source of enrichment where adverse effects are high, higher densities farther away where enrichment is still high but toxicity lower, and intermediate densities at distant sites unaffected by enrichment. Infaunal densities sampled along gradients of intense enrichment caused by sewage discharge and oil pollution have tended to show this pattern (Pearson \& Rosenberg 1978. Sandulli \& De Nicold 1991). Field experiments conducted by Spies et al. (1988) also were generally consistent with this pattern of increased densities under conditions of moderate enrichment. After $35 \mathrm{~d}$ outplanted experimental sediments that had low concentrations of added organic matter (dry kelp debris or seep petroleum) had higher species richness and overall abundance of meiofauna $(<0.5 \mathrm{~mm}$ ) and macrofauna ( $>0.5 \mathrm{~mm}$ ) than sediments with higher concentrations of organic materials.

Clearly, assessments of anthropogenic effects on benthic communities (e.g. caused by oil or sewage) will be greatly enhanced if the response to organic enrichment is understood. Natural oil seeps provide a unique opportunity to study the effect of chronic oil discharges and the tradeoff between enrichment and toxicity (Spies \& Davis 1979, Spies et al. 1980, Spies \& DesMarais 1983, Montagna \& Spies 1985, Bauer et al. 1988, Montagna et al, 1989). In addition to having a toxic effect, oil from seeps can contribute additional organic carbon which is utilized by a diverse bacterial and meiofaunal community. The additional organic matter (degraded oil, bacteria, meiofauna) can result in a greater food supply for macrofaunal organisms and an enhancement of densities of some infaunal species in seepage areas. Further, the locally patchy distribution of zones of seepage within any given seep site offers the potential to examine the effects of very small-scale gradients in enrichment and toxicity in addition to patterns that arise among sites with and without seeps.

Here we explore relationships among densities of infaunal organisms and several chemical and physical measures of sediments to determine how infaunal abundances are related to the level of oil contamination within an area of active oil seepage. Within the localized area of an oil seep, sediments vary greatly in degree of oil contamination on scales of a few meters. One major goal was to understand the relationships between physical and chemical aspects of the sediment and the degree of oil contamination, and then explore whether small-scale spatial patterns of abundance of macrofauna could be explained using this information. Chemical and physical characteristics of the sediments might act as cues for colonization and might explain some of the variation in the spatial distribution of the taxa at oil seeps. Another goal was to assay movements of macrofauna using short (24 h) colonization experiments to reveal whether movements can help account for the observed spatial variation in infaunal abundance at the oil seeps (Pearson \& Rosenberg 1978). Finally, we also examined patterns of colonization at larger spatial scales (seep and non-seep areas separated by several hundred meters).

\section{MATERIALS AND METHODS}

Description of sites. All sampling and experiments were conducted at the Isla Vista oil seeps (34 $24^{\prime} \mathrm{N}$, $119^{\circ} 53^{\prime} \mathrm{W}$ ) and other sites (without seeps) located off Coal Oil Point, Santa Barbara, California. Isla Vista Seep (Allen \& Mikolaj 1970, Spies et al. 1980) is a $1000 \mathrm{~m}^{2}$ area at a water depth of $20 \mathrm{~m}$ approximately $1 \mathrm{~km}$ east of Coal Oil Point. Within the seep there is one large $50 \mathrm{~m}^{2}$ area of intense methane seepage and many smaller methane and oil seeps 0.1 to $2.0 \mathrm{~m}^{2}$ in area (Spies et al. 1980) separated by relatively uncontaminated sediments.

Spatial variation in macrofaunal density and physicochemical characteristics. The relationship between the abundance of infauna and sediment characteristics within a seep area was determined by collecting and analyzing biological and sediment cores at a total of 74 locations at Isla Vista Seep on December 18-20, 1990. All samples were collected by divers using SCUBA. Sampling locations were within a few meters of each other and were chosen on the basis of surface sediment conditions, with some samples taken in areas that appeared to be heavily oiled and others where the surface sediments were clean. Although amounts of hydrocarbons in each sample were subsequently measured (see below), this visual assessment during the sampling procedure helped obtain a range of sediment conditions for our analyses. At each sampling location 1 core to assess infaunal density and 6 smaller cores to assess physicochemical characteristics were collected (Table 1). An infaunal can corer $\left(78 \mathrm{~cm}^{2}\right)$ was carefully placed on the sediment. Each infaunal corer had its top covered with $0.25 \mu \mathrm{m}$ Nitex mesh to allow water to escape and prevent loss of animals. After placement of the infaunal corer, six plastic syringe cores ( $6 \mathrm{~cm}^{2}$ per core), to be used for analysis of physicochemical characteristics, were inserted into the sediment next to each infaunal core to a depth of 5 to $8 \mathrm{~cm}$. The infaunal corers were then inserted to a depth of $10 \mathrm{~cm}$ (or less if underlying solid substrate was encountered), and all cores (syringe and infaunal) were capped and removed. The top $5 \mathrm{~cm}$ is where most 
sample comprised by dried oil on the 3 largest sieves (2, 1 and $0.5 \mathrm{~mm})$.

Infauna: In this study we focused primarily on the size fraction of the infauna typically referred to as macrobenthos, which were all organisms retained on a $0.5 \mathrm{~mm}$ sieve following preservation in formalin. The meiobenthos is smaller than $0.5 \mathrm{~mm}$. Sieving after preservation helped retain long narrow animals that might otherwise crawl through the sieve if not first preserved. To facilitate sorting, animals were sieved through $0.85,0.5,0.4$ and $0.3 \mathrm{~mm}$ sieves and stored in $70 \%$ ethanol. A total of 26 samples representing a range of oil contamination were sorted and the infauna in all size fractions identified to broad taxonomic groups (see Table 1) and counted. Only taxa with an average abundance of $>2$ individuals per sample were considered in the analyses.

We first explored whether abundances of each of the major groups in the macrobenthos fraction were correlated with those in the meiobenthos fraction (retained on the 0.3 and $0.4 \mathrm{~mm}$ screens in our sorting). This was important since some groups (e.g. nematodes) have substantial fractions of individuals that fall below the usual size cutoff for macrobenthos (i.e. $0.5 \mathrm{~mm}$ ). For 8 of the 9 taxa (listed on Table 1) there was a significant positive correlation in abundances between 'large' (>0.5 mm) and 'small' (0.3 to $0.5 \mathrm{~mm})$ individuals in the samples $(n=26$ each analysis, Pearson's $r=0.38$ to 0.81 , all $p$ values $<0.05$ ). The exception was cumaceans (Pearson's $r=0.27, p=0.18, n=26$ ). For all 9 taxonomic groups, including cumaceans, the total density (i.e. using all sieves) was significantly correlated with the density in the larger fraction (mean $r=0.85$, range 0.51 to $0.96, \mathrm{n}=26$ for all groups). Because our experimental studies focused only on the macrobenthos (>0.5 mm, see below), and because this cutoff is standard in macrobenthos studies (e.g. Thrush et al. 1996), we restricted all subsequent analyses to the $0.5 \mathrm{~mm}$ fraction. The strong correlations between size fractions indicate that our conclusions are robust to this decision (see also James et al. 1995 and Spies et al. 1988).

Analysis: All chemical and physical variables, except $\mathrm{C}: \mathrm{N}$ and TDS, were arcsine square-root transformed to homogenize variances associated with data expressed as proportions. $C: N$ was not transformed. TDS was $\log _{10}(x+1)$ transformed. Infaunal densities were square root $(x+0.5)$ transformed to homogenize variances (Sokal \& Rohlf 1981)

Because of the high correlation among the physical and chemical variables, principal components analysis (PCA; SAS 1988) was used to simplify the observed variation in these environmental parameters. The PCA. axes were interpreted by examining the loadings (correlations) between the axes and the original variables. To characterize each sampling location, PCA scores were calculated and used as environmental descriptors in subsequent analyses. In preliminary analyses, axes were rotated by the quartimax technique; however, because rotation did little to aid in interpreting the PCAs and because the general conclusions were robust to rotation, only the unrotated loadings and scores are reported here.

The spatial variation of infauna was also summarized using PCA, which simplified the overall variation in infaunal density and helped define groups that responded similarly to organic enrichment and sediment characteristics.

A field test of the effect of different forms of organic enrichment. We conducted a field experiment to assess the response of mobile macrofauna to different components of oil contamination by quantifying their colonization of trays of initially azoic sediments. Trays were filled with either clean sediment, sediment treated with oil (weathered or fresh: see below) or sediment enriched with sulfide, placed in the field for $24 \mathrm{~h}$, and retrieved. We focused on the short-term colonization of sediments by benthic juveniles and adults (rather than larval recruitment) to isolate the effect of microhabitat choice by the life stages that we focused on in the main survey. These organisms could colonize the sediments either by movement in the water column (e.g. at night for so-called demersal zooplankton) or by crawling along the sediments into the trays.

Each tray contained approximately $1205 \mathrm{~g}$ of clean sediment that was obtained by sieving silica sand (California Silica Products Co., CA, USA) through a $0.4 \mathrm{~mm}$ sieve. Four treatments were made: clean sand, clean sand and fresh oil, clean sand and weathered oil, and clean sand and sulfide. Oil for the 'fresh oil' and 'weathered oil' treatments was collected from the oil seeps by inverting 2 plastic buckets over an area of intense oil seepage. A small hole was drilled in the bottom of each bucket to prevent an accumulation of methane gas. The buckets were anchored and retrieved after one week. The oil was poured into another bucket, covered, and stored at $-25^{\circ} \mathrm{C}$ until needed for the experiment.

The fresh oil treatment was made by adding 36 to $44 \mathrm{~g}$ of oil to the sand in a $23 \times 23 \times 5.5 \mathrm{~cm}$ plastic container (Superseal, APL Corp., Miami Beach, FL, USA) the night before the experiment was conducted. The weathered oil treatment was identical to the oil treatment except that the trays were filled with raw seawater, covered, and incubated in a darkened seawater tank for $7 \mathrm{~d}$ before being placed in the field. Trays were shaken daily to ensure that the oil was exposed to the bacteria in the water.

The sulfide treatment was prepared by placing $10 \mathrm{~g}$ of sodium sulfide crystals in a sediment tray and then adding $1205 \mathrm{~g}$ of silica sand. Over the course of the 
experiment the crystals dissolved, releasing sulfide. This was confirmed by placing 4 sulfide sediment trays in the laboratory seawater system for $24 \mathrm{~h}$ and then analyzing the sediment for dissolved sulfide by the same method used in the distribution survey. These analyses revealed concentrations of $12375 \pm 3811 \mu \mathrm{M}$ total dissolved sulfide (mean $\pm 1 \mathrm{SE}$ ). This was higher than measured in our field surveys, but within the range seen in the marine environment (Bagarinao 1992). Since this sampling method measured total dissolved sulfides in cores from the entire vertical profile in the trays, we were not able to determine if levels of sulfides near the sediment surface were lower, as would be expected if oxidation were occurring.

On October 14, 1992, 10 replicates of each treatment (fresh oil, weathered oil, sulfide, control) were placed at the area of intense methane seepage at Isla Vista Seep. Trays were filled with raw seawater at the surface, covered, and placed randomly on the bottom in a $6 \times 8$ array by divers. Trays were placed $0.5 \mathrm{~m}$ apart from each other to minimize interference between treatments and to match the spatial scale of oil seepage at the seeps. The trays were uncovered, left overnight, and retrieved the next day. The contents of each tray were transferred to a plastic bucket and fixed with buffered formalin to a final concentration of $10 \%$. Samples were sieved through a $0.5 \mathrm{~mm}$ sieve and stored in $70 \%$ ethyl alcohol, and all macrofauna were later identified to broad taxonomic groups and counted. Analyses are based only on taxa with an average abundance $\geq 1$ per tray.

Abundances were square root $(x+0.5)$ transformed to meet the assumption of homogeneity of variance (Sokal \& Rohlf 1981). A priori orthogonal contrasts (Day \& Quinn 1989) were done for each taxon: clean versus treated sediments, sulfide versus oiled sediments, fresh oil versus weathered oil.

Comparison of abundance of mobile infauna among seep and non-seep sites. To facilitate comparison between our work and previous work (which was conducted on a larger spatial scale), we also conducted a study examining the colonization of trays by organisms at 2 seepage sites and 2 sites that lacked seeps. We did this by placing plastic trays containing clean sediments at 4 sites that were similar in depth, sediment type and exposure. All sites were located on the $20 \mathrm{~m}$ depth isobath. West Seep, a $1000 \mathrm{~m}^{2}$ area, has three $50 \mathrm{~m}^{2}$ areas of intense methane gas seepage, with low hydrocarbon seepage, separated by $20 \mathrm{~m}$ of relatively clean sand. West Comparison is located about $75 \mathrm{~m}$ east of West Seep and has no methane or oil seepage. East Seep (Isla Vista Seep; Spies et al. 1980) is a $1000 \mathrm{~m}^{2}$ area (Allen \& Mikolaj 1970) $75 \mathrm{~m}$ east of West Comparison and was the site of the field survey in this study. East Comparison is $150 \mathrm{~m}$ east of East Seep and has no methane or oil seepage.
On August 26, 1992, 10 sediment trays were placed a minimum of $2 \mathrm{~m}$ apart at each of the 4 sites (West Seep, West Comparison, East Seep, and East Comparison). Trays were filled with seawater at the surface, covered, and placed on the bottom by divers. The trays were then uncovered and left overnight. Following retrieval, the trays were transferred to plastic buckets and fixed with $10 \%$ formalin. Contents were sieved through a $0.5 \mathrm{~mm}$ sieve, and stored in $70 \%$ ethyl alcohol. Retained organisms were identified to major taxonomic groups and counted.

\section{RESULTS}

\section{Spatial variation in macrofaunal density and physicochemical characteristics}

\section{Physical and chemical characteristics}

The chemical and physical variables strongly covaried among sites; thus principal components analysis (PCA) provided an efficient way to summarize the data. The first PC axis in the analysis of the chemical and physical variables (ENVPC1; we use the prefix ENV to distinguish physicochemical analyses from those of infauna) explained $53 \%$ of the total variation in the chemical and physical variables, and appeared to represent a general gradient in oil contamination (Table 2). All of the chemical variables and the 3 largest sediment size classes loaded positively on ENVPC1, whereas the 3 smallest sediment classes loaded negatively. The second axis (ENVPC2) represented primarily variation related to non-oil organics, and is illustrated by the positive loadings of NOO and other generic measures of organics (TVS, TOC, TON, $\mathrm{C}: \mathrm{N}$ ). The variation in ENVPC3 is primarily associated with variation in TAR and GS2 (gravel). It is important to note that dried oil was most common on the largest soil size fraction (gravel) and thus variation in TAR was expected to contribute significantly to the observed variation in GS2; this redundancy is borne out by the large loadings of TAR and GS2 on ENVPC3. Sulfide was the only variable that loaded strongly on ENVPC4.

\section{Infauna}

The relationship between the infaunal abundances and the physicochemical characteristics of the sediment indicated that each taxonomic group was correlated with many closely related environmental variables. This relationship was simplified by conducting a correlation analysis between the infaunal abundances and the physicochemical principal components 
Table 2. Principal components analysis with chemical and physical environmental (ENV) variables from the survey at lsla Vista Seep. All variables were transformed as described in text. The highest loading for each variable is underlined. ENVPC1 represents the overall variation in chemical and physical variables. ENVPC2 is associated with variation in organics and non-oil organic matter. The variation in ENVPC3 is associated with TAR and GS2, characteristics of 'weathered' oil. ENVPC4 represents, predominantly, variation in sulfide. The 4 axes account for $85 \%$ of the total variability in the environmental variables; percent variation explained is given under each

\begin{tabular}{|c|c|c|c|c|c|}
\hline & $\begin{array}{c}\text { ENVPC1 } \\
53 \%\end{array}$ & $\begin{array}{c}\text { ENVPC2 } \\
13 \%\end{array}$ & $\begin{array}{c}\text { ENVPC } 3 \\
12 \%\end{array}$ & $\begin{array}{c}\text { ENVPC4 } \\
7 \%\end{array}$ & \\
\hline TEH & 0.856 & -0.124 & 0.110 & 0.177 & Hydrocarbons \\
\hline TAR & 0.394 & -0.287 & 0.830 & -0.106 & Tar \\
\hline TDS & 0.364 & 0.032 & -0.131 & 0.740 & Sulfide \\
\hline TVS & $\underline{0.876}$ & 0.433 & -0.030 & -0.007 & Volatile solids \\
\hline TOC & 0.853 & 0.468 & 0.117 & 0.015 & Organic carbon \\
\hline TON & 0.759 & 0.435 & 0.072 & 0.211 & Organic nitrogen \\
\hline$C: N$ & 0.793 & 0.408 & 0.171 & -0.146 & TOC:TON \\
\hline $\mathrm{NOO}$ & 0.267 & $\underline{0.783}$ & -0.125 & -0.257 & Non-oil organics \\
\hline GS2 & 0.539 & -0.225 & 0.769 & -0.078 & Gravel \\
\hline GS1 & $\underline{0.855}$ & -0.201 & 0.154 & 0.076 & Very coarse sand \\
\hline GSOS & 0.891 & -0.276 & -0.306 & 0.028 & Coarse sand \\
\hline GSO25 & 0.770 & -0.286 & -0.389 & -0.292 & Medium sand \\
\hline GS0125 & -0.621 & 0.266 & 0.158 & -0.344 & Fine sand \\
\hline cis0063 & -0.858 & 0.311 & 0.298 & 0.217 & Very fine sand \\
\hline GS0000 & -0.804 & 0.301 & 0.279 & 0.262 & Silt and clay \\
\hline
\end{tabular}

Table 3. Average abundance (and 1 SE per $78 \mathrm{~cm}^{2}$ ) of each taxon, and correlations between abundance and the environmental principal components (from Table 2) at Isla Vista Seep. Pearson correlation coefficients that are significant $(p<0.05$ for $n=26)$ are underlined

\begin{tabular}{|c|c|c|c|c|c|}
\hline & Average abundance & ENVPC1 & ENVPC2 & ENVPC 3 & ENVPC4 \\
\hline \multicolumn{6}{|l|}{ Group 1} \\
\hline Nematodes & $228.2 \pm 90.6$ & 0.24 & -0.12 & -0.11 & $\underline{0.39}$ \\
\hline \multicolumn{6}{|l|}{ Group 2} \\
\hline Polychaetes & $62.1 \pm 8.0$ & -0.66 & 0.22 & 0.29 & 0.20 \\
\hline Gammarids & $10.4 \pm 1.9$ & $-\underline{0.60}$ & 0.11 & 0.17 & 0.09 \\
\hline Oligochaetes & $9.1 \pm 1.9$ & $-0 . \overline{47}$ & -0.17 & 0.14 & 0.14 \\
\hline Bivalves & $7.0 \pm 0.9$ & -0.40 & 0.05 & $\underline{0.40}$ & -0.22 \\
\hline Copepods & $6.8 \pm 1.7$ & -0.51 & 0.16 & 0.04 & 0.37 \\
\hline Misc, worms & $6.5 \pm 1.3$ & -0.54 & $\underline{0.42}$ & 0.14 & 0.24 \\
\hline Ostracods & $3.6 \pm 0.8$ & $-\underline{0.46}$ & 0.41 & 0.10 & -0.02 \\
\hline \multicolumn{6}{|l|}{ Group 3} \\
\hline Cumaceans & $2.1 \pm 0.5$ & -0.20 & -0.22 & -0.09 & -0.46 \\
\hline
\end{tabular}

obtained in the ENVPC analysis above (Table 2). The density of each higher taxon was significantly correlated with at least one of the multivariate descriptions of the physicochemical environment (Table 3). The correlations were strongest and most consistent for the first environmental principal component (ENVPC1; Table 3), which provided a general index of oil contamination (Table 2). Of the 9 groups, 7 were significantly negatively correlated with ENVPC1, indicating that their densities were greatest in the sites with the lowest amount of oil seepage. In addition, bivalves were associated with ENVPC3 (larger sediments), while ostracods and miscellaneous worms were associ- ated with ENVPC2 (higher concentrations of NOO material). Cumacean density was negatively associated with ENVPC4, which was associated with sulfide concentration. Only nematodes displayed a pattern indicating a preference for contaminated sediments: their density was weakly (but positively) correlated with oil contamination (ENVPC1) and significantly (and positively) correlated with sulfide concentration (ENVPC4)

We also used PCA to summarize the variation in density of the infaunal taxa (Table 4 ; the axes have the prefix INF to indicate that they summarize data on infauna). INFPC1 explained $52 \%$ of the variation in 
infaunal abundance, with nematodes loading negatively on INFPC1, while all other groups loaded positively. INFPC 2 explained $14 \%$ of the variation in abundances (Table 4), due mostly to the positive loading by cumaceans. INFPC 3 explained an additional $12 \%$ of the variation in infaunal abundances and was associated, primarily, with increasing densities of nematodes and oligochaetes (Table 4).

Relationships between the results of the physicochemical and infaunal principal components further demonstrated the strong association of infaunal densities and oil contamination (Table 5). INFPC1 was negatively correlated with ENVPC1, indicating that the major source of variation in macrobenthic abundances is strongly related to the major source of variation in the physical/chemical environment. Thus, most of the variation in infaunal density (INFPC1) can be explained by variation in oil contamination (ENVPC1).

Table 4. Principal components analysis of infaunal (INF) abundances at Isla Vista Seep. Abundances were square $\operatorname{root}(x+0.5)$ transformed. The highest loading for each variable is underlined. INFPC1 represented variation in all of the infauna, although cumaceans loaded more highly on INFPC2. The variation in INFPC3 was primarily associated with variation in nematodes, oligochaetes, and copepods. The first 3 axes accounted for $78 \%$ of the variation in the infaunal abundances; percent variation explained is given under each

\begin{tabular}{|lccc|}
\cline { 2 - 4 } & $\begin{array}{c}\text { INFPC1 } \\
52 \%\end{array}$ & $\begin{array}{c}\text { INFPC2 } \\
14 \%\end{array}$ & $\begin{array}{c}\text { INFPC3 } \\
12 \%\end{array}$ \\
\hline $\begin{array}{l}\text { Group 1 } \\
\text { Nematodes }\end{array}$ & $-\underline{0.640}$ & -0.241 & 0.535 \\
Group 2 & & & \\
$\quad$ Polychaetes & $\underline{0.913}$ & -0.179 & 0.102 \\
Gammarids & $\underline{0.918}$ & 0.126 & 0.205 \\
Oligochaetes & 0.555 & 0.248 & 0.600 \\
Bivalves & $\underline{0.747}$ & 0.339 & -0.234 \\
Copepods & $\underline{0.693}$ & -0.361 & 0.408 \\
Misc. worms & $\underline{0.811}$ & -0.420 & -0.142 \\
$\quad$ Ostracods & $\underline{0.747}$ & -0.139 & -0.386 \\
Group 3 & & & \\
Cumaceans & 0.238 & $\underline{0.826}$ & 0.104 \\
\hline
\end{tabular}

Table 5. Correlations between the infaunal principal components (Table 4) and the environmental principal components (Table 2) from the Isla Vista Seep survey. Pearson correlation coefficients that are significant $(p<0.05$ for $n=26)$ are underlined

\begin{tabular}{|lcccc|}
\hline & ENVPC1 & ENVPC2 & ENVPC3 & ENVPC4 \\
\hline INFPC1 & $-\underline{0.65}$ & 0.22 & 0.23 & 0.06 \\
INFPC2 & 0.03 & -0.38 & 0.00 & $-\underline{0.60}$ \\
INFPC3 & -0.20 & -0.28 & -0.05 & $\underline{0.42}$ \\
\hline
\end{tabular}

The other 2 major descriptions of the variation in infaunal abundances were also associated with environmental patchiness: i.e. INFPC2 was negatively correlated with ENVPC4 and INFPC3 was positively correlated with ENVPC4.

The PCA suggest that the variation in infaunal density was driven by variation in hydrocarbon contamination. However, these analyses provide little insight into the magnitude of these effects. To address this issue, we used ENVPC1 (which was the major axis representing hydrocarbon contamination) to define a group of relatively 'clean' samples (ENVPC $1<0.0, \mathrm{n}=$ 15 samples) and a group of relatively contaminated samples (ENVPC1 > 2.0, $n=4$ ). For these 2 groups, we calculated the mean density of each infaunal group and physicochemical variable (Table 6). Nematodes were twice as abundant in the contaminated sediments than in the cleaner sediments. Several groups (gammarids, copepods, ostracods) were completely absent from the contaminated sediments. The environmental gradient producing these responses was striking, and often involved an order of magnitude increase in parameter values going from the clean to contaminated sediments (Table 6).

\section{A field test of the effect of different forms of organic matter}

The colonization experiment revealed patterns consistent with the field survey (Figs. 1 \& 2). Nematodes were the only taxon that had higher densities in the oil and sulfide treatments than in the control (Fig. 1), whereas all other groups (polychaetes, harpacticoids, cumaceans, gammarids, ostracods, ophiuroids) had their greatest abundances in the control (Fig. 2). There was relatively less variation in response among the 3 contaminated treatments, although there was a tendency for organisms to be more abundant in the weathered oil treatment than the fresh oil treatment. Densities in the trays ranged from as much as $26.7 \%$ of the density in nearby sediments (cumaceans) to less than $1 \%$ (polychaetes), probably indicating variation in their proclivity to enter the water column and thus disperse to new sites (Steichen 1994).

\section{Comparison of abundance of mobile infauna among sites}

Analysis of colonization of sediment trays placed at seep and clean sites revealed that all taxa had higher abundances at the sites with oil seepage (Table 7). Nematodes were too rare in this data set to permit analysis. 
Table 6. Abundance of macrofauna (no. per core) and values of environmental measurements (all mean $\pm 1 \mathrm{SE}$ ) from Isla Vista Seep samples with high ( $n=4)$ and low ( $n=15$ ) levels of oil contamination. High and Low were defined by ENVPC1 (High: $>2.0$ i Low: $<0.0$ ). Also shown is the percent change (High - Low / Low $\times 100 \%$ ) in each variable to facilitate comparisons. All environmental parameters are expressed as proportion of dry mass except as indicated in footnotes; see 'Materials and methods' for details

\begin{tabular}{|c|c|c|c|}
\hline & High & Low & $\begin{array}{l}\text { Percent } \\
\text { change }\end{array}$ \\
\hline \multicolumn{4}{|l|}{ Macrofauna } \\
\hline Nematodies & $291.0(152.7)$ & $102.4(67.3)$ & +184 \\
\hline Polychaetes & $9.5(3.17)$ & $73.9(8.9)$ & -87 \\
\hline Gammarids & $0.0(0.0)$ & $12.5(2.3)$ & -100 \\
\hline Oligochaetes & $1.8(1.8)$ & $10.9(2.9)$ & -84 \\
\hline Bivalves & $2.5(1.6)$ & $7.7(0.9)$ & -77 \\
\hline Copepods & $0.0(0.0)$ & $9.3(2.7)$ & -100 \\
\hline Misc. worms & $0.3(0.3)$ & $8.5(1.7)$ & -97 \\
\hline Ostracods & $0.0(0.0)$ & $4.3(0.9)$ & -100 \\
\hline Cumaceans & $1.0(0.7)$ & $2.3(0.7)$ & -57 \\
\hline \multicolumn{4}{|c|}{ Environmental parameters } \\
\hline TEHa & $0.048(0.013)$ & $0.002(0.0003)$ & +2575 \\
\hline TAR & $0.075(0.051)$ & $0.015(0.003)$ & +402 \\
\hline $\operatorname{TDS}^{\mathrm{b}}$ & $2730.00(880.36)$ & $560.60(164.31)$ & +387 \\
\hline TVS & $0.104(0.045)$ & $0.014(0.001)$ & +643 \\
\hline TOC & $0.043(0.015)$ & $0.004(0.0004)$ & +968 \\
\hline TON & $0.001(0.0002)$ & $0.0004(0.00002)$ & +185 \\
\hline $\mathrm{C}: \mathrm{N}^{\mathrm{c}}$ & $36.02(8.50)$ & $11.67(1.19)$ & +209 \\
\hline $\mathrm{NOO}$ & $0.048(0.037)$ & $0.012(0.001)$ & +308 \\
\hline GS2 & $0.086(0.048)$ & $0.009(0.002)$ & +774 \\
\hline GS1 & $0.166(0.033)$ & $0.004(0.001)$ & +3402 \\
\hline GS05 & $0.223(0.066)$ & $0.007(0.001)$ & +3263 \\
\hline GS025 & $0.291(0.084)$ & $0.040(0.012)$ & +619 \\
\hline GS0125 & $0.147(0.069)$ & $0.389(0.016)$ & -62 \\
\hline GS0063 & $0.082(0.074)$ & $0.499(0.023)$ & -84 \\
\hline GS0000 & $0.005(0.005)$ & $0.049(0.005)$ & -90 \\
\hline $\begin{array}{l}{ }^{2} \text { Proportion wet } \\
{ }^{\mathrm{b}} \mu \mathrm{M} \mathrm{S}= \\
{ }^{c} \text { Dimensionless }\end{array}$ & & & \\
\hline
\end{tabular}

The relationship between infauna and sediment characteristics in areas with organic enrichment has received much attention (Gray 1974, Pearson \& Rosenberg 1978, Aller 1983, McCall \& Tevesz 1983, Rhoads \& Boyer 1983, Agard et al. 1993). Sediment characteristics have a tremendous influence on the composition of the infaunal community. For example, following organic enrichment, particulate organic material in sediments can increase as a result of bacterial degradation of the material (see Pearson \& Rosenberg 1978, Weston 1990), resulting in an increase in the proportion of finer sediments. In contrast, organic enrichment, particularly via oil pollution, can result in an increase in sediment size by increasing aggregation, e.g. causing the formation of tar balls (Pearson \& Rosenberg 1978, Spies \& Davis 1979). This latter possibility is supported by our survey patterns, which show increased sediment size in the most contaminated samples. Although we did not investigate this mechanism experimentally, it is clear that this effect was likely responsible for at least a portion of the infaunal response we observed.

In addition to sediment size, other sediment characteristics are also thought to play important roles in shaping infaunal communities. For example, organically enriched areas are typically comprised of deposit-feeding taxa because of their tolerance to increased organic material, and a decrease in available oxygen and associated increase in sulfide. This is the case at

\section{DISCUSSION}

\section{Environmental effects of organic enrichment} the oil seeps where the infaunal community was described by Spies \& Davis (1979) as being composed largely of deposit feeders. Among these organisms, nematodes display one of the greatest positive
While other research has focused on the overall response of macrofauna to organically enriched sediments (Pearson \& Rosenberg 1978), little has been done to separate the effect on infauna of organic enrichment from secondary factors such as changes in chemical and physical sediment characteristics. Indeed, the biological responses to organic enrichment at the seep sites we studied were associated with many environmental variables, making it difficult or impossible to isolate the functional role of different variables.
Table 7. Mean ( $1 \mathrm{SE}$ ) infaunal abundances (per $530 \mathrm{~cm}^{2} ; \mathrm{n}=10$ ) in trays of clean sediment placed at 2 seep and 2 non-seep (comparison) areas for a $24 \mathrm{~h}$ period. Means connected by the same line are not significantly different $(p>0.05)$

\begin{tabular}{|c|c|c|c|c|}
\hline & \multicolumn{2}{|c|}{ Seep } & \multicolumn{2}{|c|}{ Comparison } \\
\hline & East & West & East & West \\
\hline Polychaetes & 7.110 .661 & $9.5(0.82)$ & $5.910 .92 \mathrm{~L}$ & $5.3(1.14)$ \\
\hline Gammarids & $21.5(4.28)$ & $24.7(2.64)$ & $11.0(1.02)$ & $11.9(0.78)$ \\
\hline Copepods & $5.7(1.50)$ & $12.0\lfloor 1.51\rfloor$ & $1.7(0.54 \mathrm{~L}$ & $0.8[0.25]$ \\
\hline Ostracods & $5.7(1.99)$ & $7.8(1.07)$ & $0.910 .31 \mathrm{~L}$ & $1.7(0.26)$ \\
\hline Cumaceans & $71.2(19.02)$ & $89.2(12.12)$ & $30.0(1.48)$ & $40.1(2.63)$ \\
\hline
\end{tabular}




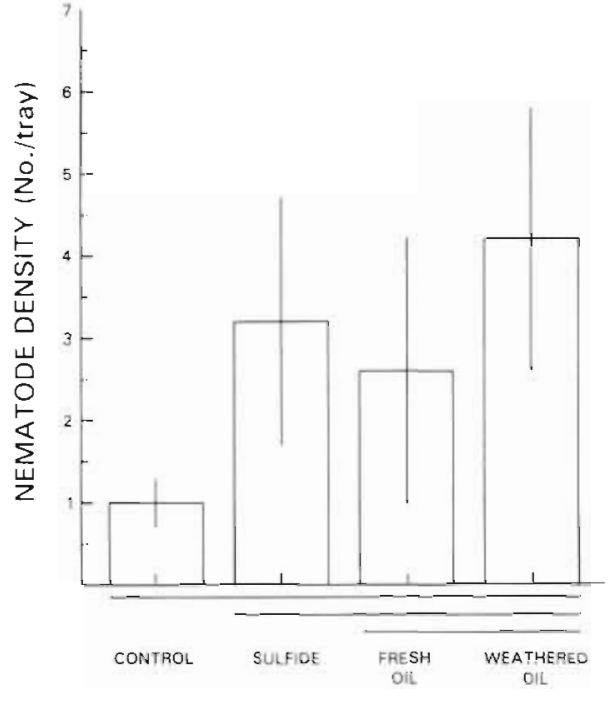

TREATMENT

Fig. 1. The response of nematodes to treated sediments placed at the oil seeps in plastic trays $\left(530 \mathrm{~cm}^{2}\right)$ for $24 \mathrm{~h}$ (mean $\pm 1 \mathrm{SE}, \mathrm{n}=10$ ). A priori orthogonal contrasts (clean vs contaminated, sulfide vs oil, fresh vs weathered oil) were not significant and are indicated by continuous lines under the graph

responses to organic enrichment and oil contamination (Davis \& Spies 1980, Spies et al. 1980, Montagna \& Spies 1985, Montagna et al. 1989, Weston 1990, Sandulli \& De Nicola 1991). For example, in a study of the effects of produced water (wastewater generated from oil and gas production), Osenberg et al. (1992) found enhanced densities of nematodes near the wastewater diffuser. These effects were not correlated with changes in sediment size, but instead, were directly related to exposure to hydrocarbons. Osenberg et al. concluded that this was a positive response to organic enrichment, much like that observed at oil seeps (Davis \& Spies 1980, this study). As observed at the Isla Vista oil seeps (which are only $40 \mathrm{~km}$ from the sites used by Osenberg et al.) other infaunal groups (i.e. other than nematodes) increased in abundance away from the source of oil contamination (in this case, the produced water diffuser). This is consistent with the positive response of nematodes to enrichment, but a negative response by other taxa that are more greatly affected by the deleterious effects of oil contamination (e.g. direct toxicity, as well as increased sulfide levels generated by microbial activity).

\section{Migration promotes local variation in density}

Migration of organisms can be very important in the colonization and establishment of disturbed and stressed areas (Pearson \& Rosenberg 1978, Davis \& Spies 1980, Santos \& Simon 1980, Van Blaricom 1982, Alongi et al. 1983, Cuomo 1985, Heip et al. 1985, Palmer et al. 1988). The patterns in infaunal abun-
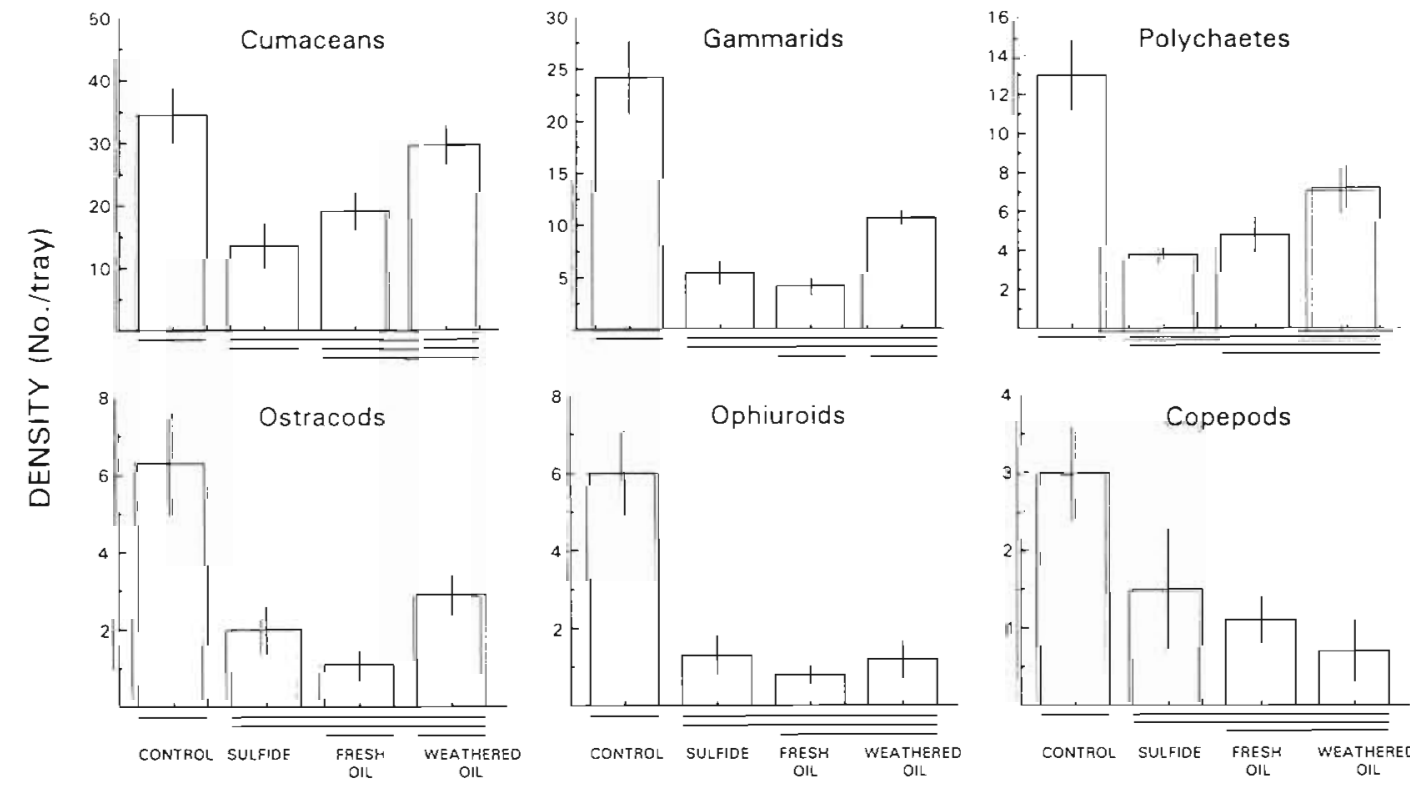

TREATMENT

Fig. 2. The response of macrofauna to treated sediments placed in trays $\left(530 \mathrm{~cm}^{2}\right)$ at the oil seeps for $24 \mathrm{~h}(\mathrm{mean} \pm 1 \mathrm{SE}, \mathrm{n}=10)$. A priori orthogonal contrasts (clean vs contaminated, sulfide vs oil, fresh vs weathered oil) are indicated by lines under each graph. A continuous line indicates no significant difference 
dance detected in our field survey might be the result of migrating organisms seeking areas characterized by a particular level of enrichment. The results of the field experiment indicate that migrating organisms respond to the treated sediments in much the same way as their densities were related to contamination in the field survey.

In the field experiment nematodes responded positively to the sulfide and oil treatments compared to the other taxa. This is consistent with the field survey as nematodes were the only taxon positively correlated with any of the indices of oil contamination. There was also a consistent negative relationship between cumaceans and sulfides in the field survey, as well as in the field experiment. Polychaetes, gammarids, ostracods, and copepods responded to the trays much as would be expected given their negative correlations with oil (ENVPC1) in the field survey. Ophiuroids, which were not abundant enough in the field survey to be included in analyses, colonized the trays in the field experiment as juveniles, 1 to $2 \mathrm{~mm}$ disc diameter, and consistently avoided the contaminated treatments.

The difference in responses of organisms to the fresh oil and weathered oil might be due to a decrease in the toxicity of the weathered oil, the establishment of a bacterial flora, or an increase in the concentration of easily used hydrocarbons. Although changes in grain size might have also played a role, we observed no obvious differences in this feature among the treatments. The establishment of a 'bio-film' or increased organic matter in the sediments of the weathered oil treatment might be important in explaining the higher abundances of some crustaceans in that treatment versus the fresh oil treatment (see Stretch 1983, 1985).

\section{Importance of spatial scale}

Earlier studies done at the Isla Vista oil seeps (Spies \& Davis 1979, Davis \& Spies 1980, Spies et al. 1980) found higher densities of organisms at the seeps than at nearby areas without oil seeps. These studies suggested that organic enrichment from the seeps is converted into useable organic matter by a well developed bacterial and meiofaunal community. This additional organic matter augments the available food for macrofauna and results in higher abundances at the seeps. This contrasts with the results of this study, which showed lower densities of all taxa, except nematodes, at the most enriched sampling locations.

This discrepancy might be the result of the spatial scale of sampling, which was very different in the 2 studies. The comparison site (no oil seepage) used by Spies \& Davis (1979) was $1.4 \mathrm{~km}$ from the seeps. In our study, only the seep site was sampled, and variation in enrichment was obtained by sampling local patches a few meters apart that varied in the amount of seepage. The most likely reason Spies et al. (1980) found higher abundances at the seeps, while we observed a negative relationship between oil contamination and infaunal abundance, is that while the seeps have localized heavily oiled areas with few organisms (detected in our surveys), bacterial decomposition of the oil overall enriches surrounding sediments. Thus, on a small spatial scale (as examined in our study), there is a negative relationship between most taxa and oil exposure, while on a larger (among site) spatial scale [as examined in our tray study and in Spies et al. (1980)] there is a general increase in infaunal densities at the seep sites. The importance of scale was also suggested by finer-scale sampling conducted by Davis \& Spies (1980), which documented depressed densities at the center of an active seep (sampling conducted over a $1 \mathrm{~m}$ gradient). Taken together, these studies provide strong evidence of a halo effect: infaunal densities are very low in the most contaminated microsites within a seep area (due to toxic effects), reach a maximum at 'clean' sites within the seepage area (due to enrichment), and are low again at distant sites (50 to $1000 \mathrm{~m}$ from the seeps) that are unaffected by oil seepage (i.e. where there is no enrichment). Sampling on an ultra-fine scale by Davis \& Spies (1980) suggested that even nematodes may show this pattern, although they may show a depression in density only at the most extreme levels of contamination; under most conditions within the seep area, nematode density responds positively to oil contamination (as shown in our survey). Thus, it appears that when compared at the scale of hundreds of meters, oil seepage enhances infaunal density, whereas on the scale of meters, oil contamination depresses the density of infauna (with the notable exception of nematodes)

Evaluations of the importance of spatial scale require that established patterns represent real responses to oil seepage. However, previous work at the seeps often lacked spatial replication and the differences observed might simply represent variation in density unrelated to the oil seeps. Our research avoided this problem in 2 ways. First, our survey of infaunal density examined small-scale variation among 26 sites located within a seep region. Thus, the associations we found (Tables 3 , $4 \& 6$ ) are not the chance result of a single very contaminated area associated with low infaunal abundance. These data strongly support interpretations made from more limited surveys conducted on a very fine scale by Davis \& Spies (1980). Second, our examination of large-scale variation in infaunal patterns demonstrated consistent patterns at 2 different seep and nearby comparison (non-seep) areas. The densities of all of the taxa were higher in the trays after $24 \mathrm{~h}$ at the oil seeps 
than at the comparison areas. If the relationship between densities of macrofauna in the surrounding sediments and the number of organisms colonizing trays is constant, as suggested by Stretch (1985), one interpretation of our experiment is that there are indeed higher densities of organisms in seep sites compared to non-seep sites. However, differences in the rates of colonization of the trays over the 24 h time period cannot be ruled out. Palmer et al. (1988) found that meiofauna colonized clean sediments more rapidly during a $23 \mathrm{~h}$ period at a seep site than at a comparison (clean) site. They attributed this to enhanced susceptibility of seep meiofauna to (passive) water column transport due to the tendency of seep meiofauna to live close to the sediment surface (Palmer et al. 1988). It is not clear that this particular mechanism was operating for the macrofauna in our colonization experiments. Spies \& Davis (1979) found no difference in vertical distribution of macrofauna between a seep and a comparison site, yet a shallower distribution of the macrofauna would be necessary at the seep site for enhanced passive transport.

Overall, our findings suggest that the response of infauna to oil contamination at natural oil seeps is related to secondary changes of the physical and chemical nature of the sediments. The responses of organisms to these physicochemical characteristics produce patterns of decreasing abundance with increasing oil contamination, when evaluated at small spatial scales within seep areas. However, the seeps provide an abundant supply of organic matter and appear to support higher densities of organisms overall than surrounding non-seep areas (i.e. when evaluated at larger spatial scales). Further research would be useful to address the exact spatial and temporal scales on which organisms are moving within and between seep and non-seep areas.

Acknowledgements. We thank A. Alldredge, J. Bauer, D. Boesch, M. Carr, T Collier, J. Knezovish, C. H. Peterson, R. Petty, R. Raimondi, R. Schmitt and R. Spies for discussions and/or comments on the manuscript. M. Carr, D. Canestro, B. Hoffman, D. Kushner, A. Martinez and P. Raimondi helped with field work and S. Anderson and J. McCullough gave technical assistance. This research was funded by the University of California Coastal Toxicology Program and by the MineraIs Management Service, U.S. Dept. of Interior under MMS Agreement No. 14-35-0001-3071. The views and conclusions in this paper are those of the authors and should not be interpreted as necessarily representing the official policies, either express or implied, of the U.S. Government.

\section{LITERATURE CITED}

Agard JBR, Gobin J, Warwick RM (1993) Analysis of marine macrobenthic community structure in relation to pollution, natural oil seepage and seasonal disturbance in a tropical environment (Trinidad, West Indies). Mar Ecol Prog Ser 92:233-243

Allen AA, Mikolaj PG (1970) Natural oil seepage at Coal Oil Point, Santa Barbara, California. Science 170:974-977

Aller RC (1983) The effects of macrobenthos on chemical properties of marine sediment and overlying water. In: McCall PL, Tevesz MJS (eds) Animal-sediment relations. Plenum Press, New York, p 53-102

Alongi DM, Boesch DF, Diaz RJ (1983) Colonization of meiobenthos in oil-contaminated subtidal sands in the lower Chesapeake Bay. Mar Biol 72:325-335

APHA (American Public Health Association), American Water Works Association, and Water Pollution Control Federation (1985) Standard methods for the examination of water and wastewater. APHA, Washington, DC

Bagarinao T (1992) Sulfide as an environmental factor and toxicant: tolerance and adaptations in aquatic organisms. Aquat Toxicol 24:21-62

Bartha R, Atlas RM (1987) Transport and transformations of petroleum: biological processes. In: Boesch DF, Rabalais NN (eds) Long-term environmental effects of offshore oil and gas development. Elsevier Applied Science, New York, p 287-341

Bauer JE, Montagna PA, Spies RB, Prieto MC, Hardin D (1988) Microbial biogeochemistry and heterotrophy in sediments of a marine hydrocarbon seep. Limnol Oceanogr 33:1493-1513

Cline JD (1969) Spectrophotometric determination of hydrogen sulfide in natural waters. Limnol Oceanogr 14 : $454-458$

Cuomo MC (1985) Sulphide as a larval settlement cue for Capitella sp. I. Biogeochemistry 1:169-181

Davis PH, Spies RB (1980) Infaunal benthos of a natural petroleum seep: study of community structure. Mar Biol 59: $31-41$

Day RW, Quinn QP (1989) Comparisons of treatments after an analysis of variance in ecology. Ecol Monogr 59:433-463

Grasshoff K, Ehrhardt M, Kremling K (eds) (1983) Methods of seawater analysis. Verlag Chemie, New York

Gray JS (1974) Animal-sediment relationships. Oceanogr Mar Biol A Rev 12:223-261

Gray JS (1981) The ecology of marine sediments: an introduction to the structure and function of benthic communities. Cambridge University Press, Cambridge

Heip C, Vincx M, Vranken G (1985) The ecology of marine nematodes. Oceanogr Mar Biol A Rev 23:399-489

James RJ, Lincoln Smith MP, Fairweather PG (1995) Sieve mesh-size and taxonomic resolution needed to describe natural spatial variation of marine macrofauna. Mar Ecol Prog Ser 118:187-198

Levin LA (1986) Effects of enrichment on reproduction in the opportunistic polychaete Streblospio benedicti (Webster): a mesocosm study. Biol Bull 171:143-160

McCall PL, Tevesz MJS (eds) (1983) Animal-sediment relations. Plenum Press, New York

Montagna PA, Bauer JE, Hardin D, Spies RB (1989) Vertical distribution of microbial and meiofaunal populations in sediments of a natural coastal hydrocarbon seep. J Mar Res 47:657-680

Montagna PA, Spies RB (1985) Meiofauna and chlorophyll associated with Beggiatoa mats of a natural submarine petroleum seep. Mar Environ Res 16:231-242

Osenberg CW, Schmitt RJ, Holbrook SJ, Canestro D (1992) Spatial scale of ecological effects associated with an open coast discharge of produced water. In: Ray JP, Englehardt FR (eds) Produced water: technological/environmental issues and solutions. Plenum Press, New York, p 387-402 
Palmer MA, Montagna PA, Spies RB, Hardin D (1988) Meiofauna dispersal near natural petroleum seeps in the Santa Barbara Channel: a recolonization experiment. Oil \& Chem Poll 4:179-189

Pearson TH, Rosenberg R (1978) Macrobenthic succession in relation to organic enrichment and pollution of the marine environment. Oceanogr Mar Biol A Rev 16:229-311

Rhoads DC, Boyer LF (1983) The effects of marine benthos on physical properties of sediments: a successional perspective. In: McCall PL, Tevesz MJS (eds) Animal-sediment relations. Plenum Press, New York, p 3-43

Sandulli R, De Nicola M (1991) Responses of meiobenthic communities along a gradient of sewage pollution. Mar Poll Bull 22:463-467

Santos SL. Simon JL (1980) Marine soft-bottom community establishment following annual defaunation: larval or adult recruitment. Mar Ecol Prog Ser 2:235-241

SAS Institute Inc (1988) SAS/STAT User's Guide, Release 603 edn. SAS Institute, Cary, North Carolina

Sokal RR, Rohlf FJ (1981) Biometry. WH Freeman and Co, San Francisco

Spies RB, Davis PH (1979) The infaunal henthos of a natural oil seep in the Santa Barbara Channel. Mar Biol 50. $227-237$

Spies RB, Davis PH, Stuermer DH (1980) Ecology of a submarine petroleum seep off the California coast. In: Geyer RA (ed) Marine environmental pollution. 1. Hydrocarbons Elsevier Press, Amsterdam, p 229-263

Spies RB, DesMarais DJ (1983) Natural isotope study of trophic enrichment of marine benthic communities by petroleum seepage. Mar Biol 73:67-71

This article was presented by C. H. Peterson (Senior Editorial Advisor), Morehead City, North Carolina, USA
Spies RB, Hardin DD, Toal JP (1988) Organic enrichment or toxicity? A comparison of the effects of kelp and crude oil in sediments on the colonization and growth of benthic infauna. J Exp Mar Biol Ecol 124:261-282

Steichen DS (1994) The response of benthic and demersal macrofauna to organic enrichment at a natural oil seep. MA thesis, University of California, Santa Barbara

Stretch JJ (1983) Habitat selection and vertical migration of sand-dwelling demersal gammarid amphipods. PhD thesis. University of California, Santa Barbara

Stretch JJ (1985) Quantitative sampling of demersal zooplankton: reentry and airlift dredge sampling comparisons. J Exp Mar Biol Ecol 91:125-136

Thompson BE, Bay SM, Anderson JW, Laughlin JD, Greenstein DJ, Tsukada DT (1989) Chronic effects of contaminated sediments on the urchin Lytechinus pictus. Environ Toxicol Chem 8:629-637

Thrush SF, Pridmore RD, Hewitt JE (1996) Impacts on softsediment macrofauna: the effects of spatial variation on temporal trends. In: Schmitt RJ, Osenberg CW (eds) Detecting ecological impacts: concepts and applications in coastal habitats. Academic Press, New York, p 49.66

US Environmental Protection Agency (EPA) (1979) Methods for chemical analysis of water and wastes. EPA-600/4-7920, Cincinnati, Ohio

Van Blaricom GR (1982) Experimental analysis of structural regulation in a marine sand community exposed to oceanic swell. Ecol Monogr 52:283-305

Weston DP (1990) Quantitative examination of macrobenthic community changes along an organic enrichment gradient. Mar Ecol Prog Ser 61:233-244

Manuscript first received: May 17, 1995

Revised version accepted: March 12, 1996 